\title{
Diversity, phylogeny and pathogenicity of Botryosphaeriaceae on non- native Eucalyptus grown in an urban environment: A case study
}

\section{Draginja PAVLIC-ZUPANC ${ }^{a *}$, Happy M. MALEME ${ }^{a}$, Barbara PIŠKUR ${ }^{c}$, Brenda D. WINGFIELD ${ }^{\mathrm{b}}$, Michael J. WINGFIELD ${ }^{\mathrm{a}}$, Bernard SLIPPERS ${ }^{\mathrm{b}}$}

${ }^{\mathrm{a}}$ Department of Microbiology and Plant Pathology, and ${ }^{\mathrm{b}}$ Department of Genetics, DST/NRF Centre of Excellence in Tree Health Biotechnology (CTHB), Forestry and Agricultural Biotechnology Institute (FABI), Faculty of Natural and Agricultural Sciences, University of Pretoria, Private Bag X20, Hatfield, Pretoria, 0028, South Africa.

${ }^{c}$ Department of Forest Protection, Slovenian Forestry Institute, Večna pot 2, SI-1000 Ljubljana, Slovenia

*Corresponding author: Draginja Pavlic-Zupanc

Phone: +27 (12) 420-3938

Fax: +27 (12) 420-3960

E-mail: pavlicdr@gmail.com

\section{Highlights}

- Five species of the Botryosphaeriaceae, Botryosphaeria dothidea, Neofusicoccum parvum, N. cryptoaustrale, N. ursorum, and N. eucalypti (Winter) Maleme, Pavlic \& Slippers comb. nov. were identified from 20 Eucalyptus spp. planted in an arboretum in Pretoria.

- With exception of N. parvum which was isolated from majority of Eucalyptus spp. the other species were isolated from limited number of Eucalyptus species indicating host-preferences. 
- Neofusicoccum eucalypti is recorded for the first time on Eucalyptus in South Africa.

\begin{abstract}
The Botryosphaeriaceae are opportunistic pathogens mostly of woody plants, including Eucalyptus. These fungi can cause cankers and die-back diseases on non-native Eucalyptus trees in South African plantations. Botryosphaeriaceae were isolated from diseased and asymptomatic twigs and leaves from 20 Eucalyptus spp. grown in a Pretoria, South Africa arboretum and its surroundings. The isolates were initially grouped based on conidial morphology and Internal Transcribed Spacer (ITS) rDNA PCR-RFLP profiles. They were further identified using DNA sequence data for the ITS rDNA and translation elongation factor 1- $\alpha($ TEF-1 $\alpha)$ gene regions and tested for pathogenicity. Five species were identified including Botryosphaeria dothidea and four Neofusicoccum species namely Neofusicoccum parvum; $N$. cryptoaustrale and $N$. ursorum that were recently described from plant tissues collected as a part of the current study; and Neofusicoccum eucalypti (Winter) Maleme, Pavlic \& Slippers comb. nov. The latter species is recorded for the first time on Eucalyptus in South Africa. Most of the identified species were collected from the leaves of 17 different Eucalyptus spp. Neofusicoccum parvum was most commonly isolated (72\% of all isolates) followed by $B$. dothidea species complex (17\%). With exception of $N$. parvum which was isolated from majority of Eucalyptus spp. the other species were isolated from limited number of Eucalyptus species indicating host-preferences. All the isolated Botryosphaeriaceae species produced lesions on inoculated Eucalyptus grandis plants that were significantly larger than those associated with the controls.
\end{abstract}

Keywords: Endophytes; die-back; latent pathogens; pathogenicity; urban habitat. 


\section{INTRODUCTION}

The Botryosphaeriaceae (Botryosphaeriales, Dothideomycetes) are among the most common fungi associated with diseases of trees and shrubs in both native and non-native environments worldwide (Slippers and Wingfield 2007; Slippers et al. 2009). These fungi are typically associated with symptoms such as branch and stem cankers, die-back as well as leaf and tip blights. Species of Botryosphaeriaceae commonly exist in asymptomatic plant tissues as endophytes or latent pathogens, causing disease symptoms at the onset of stressful environmental conditions (Slippers and Wingfield 2007; Mehl et al. 2013). Their cryptic nature as endophytes combined with increasing occurrences of extreme weather conditions due to climate change makes these fungi threatening to economically and environmentally important woody plants globally (Desprez-Loustau et al. 2006).

The taxonomy of the Botryosphaeriaceae has been confused in the past. Identification was commonly achieved based on morphological characteristics or the host plants on which species were found. The many overlapping morphological characteristics among different species of the Botryosphaeriaceae and the fact that some morphological features change with age has also resulted in a substantially misleading taxonomy for these fungi. Recent taxonomic studies, combining morphological characters and multigene phylogenies, have led to extensive revisions of the taxonomy of the Botryosphaeriaceae (Crous et al. 2006; Liu et al. 2012; Phillips et al. 2013; Slippers et al. 2013). Based on these analyses, the identities of Botryosphaeriaceae species known from culture has been revised, and they have been placed in 17 genera currently recognised in this family (Phillips et al. 2013; Slippers et al. 2013).

Eucalyptus trees have been planted as non-natives in many parts of the world, including South Africa. It has been previously suggested that the global movement of these trees has also resulted in the introduction of pathogens into new areas via planting stock or 
seed (Wingfield et al. 2001, 2015). In this regard, species of Botryosphaeriaceae have been found on the seeds of Eucalyptus and other tree species (Lupo et al. 2001; Gure et al. 2005). Their association with seeds and their presence in asymptomatic plant tissues provides evidence that species of Botryosphaeriaceae can be expected to be easily moved unnoticed into new areas together with Eucalyptus (Slippers and Wingfield 2007; Slippers et al. 2009).

Species of Botryosphaeriaceae have wide host ranges and they can move between native and introduced tree species (Slippers and Wingfield 2007; Sakalidis et al. 2011). For example, no restrictions to gene flow between non-native Eucalyptus globulus plantations and native eucalypt forests in Western Australia could be found in the canker pathogen Neofusicoccum australe (Burgess et al. 2006). Similarly, all species of Botryosphaeriaceae identified from the native Syzygium cordatum in South Africa, were found to be more pathogenic on Eucalyptus, with a several of these species overlapping in occurrence between the two hosts (Pavlic et al. 2007). Consequently, Eucalyptus can be expected to acquire new species of Botryosphaeriaceae from the surrounding trees in a new area, and to provide a source of species to native plant communities.

An arboretum of 20 different Eucalyptus spp. has been established in Pretoria, South Africa, in 2001, to provide a food-source for Koala Bears at the nearby National Zoological Gardens of South Africa (www.nzg.co.za). Canker and die-back symptoms were observed on these trees and an attempt was made to identify and characterize species of Botryosphaeriaceae on these trees, as well as on apparently healthy E. camaldulensis trees growing near the arboretum. This was achieved using (ITS) rDNA PCR-RFLP profiles, DNA sequence data for the ITS rDNA and translation elongation factor 1- $\alpha$ (TEF-1 $\alpha)$ gene regions of cultures isolated from these trees. Inoculations were also conducted to consider the pathogenicity of the identified species. 


\section{MATERIALS AND METHODS}

\section{Isolates}

Isolations were made from 20 Eucalyptus spp. in the Pretoria Zoological Garden (www.nzg.co.za) arboretum in Pretoria, South Africa (Fig. 1a), as well as from surrounding eucalypt trees planted as ornamentals in the area (Table 1). The arboretum consisted of 12 blocks, each of them having 20 rows (each row representing one Eucalyptus species) of 11 trees. Three trees (tree 1, 5 and 10 of each row) were sampled from three of the blocks (block 1, 6 and 7), thus having in total 9 trees sampled per each Eucalyptus sp. In addition, twentyfive Eucalyptus camaldulensis trees surrounding the arboretum were sampled. Twig die-back on terminal leader shoots (Fig. 1a) and main stem cankers, identified as cracks in the bark exuding kino (Figs 1b, c), were observed on approximately $10 \%$ of these trees. Cankers were spread widely on the trunks of some trees that appeared reddish in colour due to the extensive production of kino, indicating variation in susceptibility between Eucalyptus spp. (Figs 1b). The trees were sampled during March and April 2005. Isolations were made from diseased and asymptomatic (visually healthy) twigs, and from asymptomatic leaves collected from 205 trees, using the protocol described by Pavlic et al. (2004). All the resulting cultures are maintained in the culture collection (CMW) of the Forestry and Agricultural Biotechnology Institute (FABI), University of Pretoria, Pretoria, South Africa. 
Table 1. Isolates representing species of the Botryosphaeriaceae considered in a phylogenetic study and pathogenicity trial

\begin{tabular}{|c|c|c|c|c|c|c|c|}
\hline Species & Isolate ID $^{\mathrm{a}, \mathrm{b}}$ & Other ID ${ }^{\mathrm{a}, \mathrm{b}}$ & Host & Country & Collector/isolator & ITS & EF \\
\hline \multirow[t]{16}{*}{ Neofusicoccum parvum } & ATCC58191 & $C M W 9081$ & Populus nigra & New Zealand & G.J. Samuels & AY236943 & AY236888 \\
\hline & CMW 10122 & & Eucalyptus grandis & South Africa & H. Smith & AF283681 & AY236882 \\
\hline & СРC22757 & & E. obliqua & Thailand & T. Trakunyingcharoen & KM006435 & KM006466 \\
\hline & CMW 23792 ${ }^{\mathrm{c}}$ & & E. dorrigoensis & South Africa & H.M. Maleme & FJ752736 & FJ752702 \\
\hline & CMW 20736 ${ }^{c}$ & & E. robusta & South Africa & H.M. Maleme & FJ752730 & FJ752704 \\
\hline & CMW 20727 & & E. microcorys & South Africa & H.M. Maleme & FJ752735 & I \\
\hline & CMW 20719 & & E. ovata & South Africa & H.M. Maleme & FJ752724 & I \\
\hline & CMW 20724 & & E. saligna & South Africa & H.M. Maleme & FJ752726 & I \\
\hline & CMW 20722 & & E. microcorys & South Africa & H.M. Maleme & FJ752727 & I \\
\hline & CMW 20720 & & E. saligna & South Africa & H.M. Maleme & FJ752728 & FJ752703 \\
\hline & CMW 20726 & & E. robusta & South Africa & H.M. Maleme & FJ752729 & 1 \\
\hline & CMW 20735 ${ }^{c}$ & & E. nicholii & South Africa & H.M. Maleme & FJ752733 & I \\
\hline & CMW 20725 & & E. scorparia & South Africa & H.M. Maleme & FJ752725 & l \\
\hline & CMW 20730 & & E. tereticornis & South Africa & H.M. Maleme & FJ752731 & l \\
\hline & CMW 20733 & & E. tereticornis & South Africa & H.M. Maleme & FJ752734 & l \\
\hline & CMW 20734 & & E. tereticornis & South Africa & H.M. Maleme & FJ752732 & 1 \\
\hline \multirow[t]{2}{*}{ N. cordaticola } & CBS 123634 & $C M W 13992$ & Syzygium cordatum & South Africa & D. Pavlic & EU821898 & EU821868 \\
\hline & CBS 123635 & CMW 14056 & S. cordatum & South Africa & D. Pavlic & EU821903 & EU821873 \\
\hline \multirow[t]{2}{*}{ N. brasiliense } & CMM1338 & & Mangifera indica & Brasil & M.W. Marques & JX513630 & JX513610 \\
\hline & CMM1285 & & M. indica & Brasil & M.W. Marques & JX513628 & JX513608 \\
\hline \multirow[t]{2}{*}{$N$. batangarum } & CBS 124924 & $C M W 28363$ & Terminalia catappa & Cameroon & D. Begoude, J. Roux & FJ900607 & FJ900653 \\
\hline & CBS 124923 & CMW 28320 & T. catappa & Cameroon & D. Begoude, J. Roux & FJ900608 & FJ900654 \\
\hline \multirow[t]{2}{*}{$\begin{array}{l}\text { Neofusicoccum sp. } \\
\text { karanda }\end{array}$} & MUCC247 & WAC12396 & $\begin{array}{l}\text { E. grandis } \times \text { E. } \\
\text { camaldulensis }\end{array}$ & Australia & T. Burgess & EU301028 & EU339513 \\
\hline & MUCC125 & & E. dunnii & Australia & G. Hardy & EU339525 & EU339514 \\
\hline \multirow[t]{2}{*}{ N. ribis } & CBS 115475 & $C M W 7772$ & Ribes sp. & USA & B. Slippers, G. Hudler & AY236935 & AY236877 \\
\hline & CBS 121.26 & CMW 7054 & Ribes rubrum & USA & N. E. Stevens & AF241177 & AY236879 \\
\hline \multirow[t]{4}{*}{ N. kwambonambiense } & CBS 123639 & $C M W 14023$ & S. cordatum & South Africa & D. Pavlic & EU821900 & EU821870 \\
\hline & CBS 123641 & CMW 14140 & S. cordatum & South Africa & D. Pavlic & EU821919 & EU821889 \\
\hline & MUCC157 & & Eucalyptus dunnii & Australia & T. Burgess & EU339522 & EU339516 \\
\hline & CMW 37399 & & E. grandis & South Africa & M. Gryzenhout & JQ744566 & JQ744587 \\
\hline \multirow[t]{2}{*}{ N. umdonicola } & CBS 123645 & $C M W 14058$ & S. cordatum & South Africa & D. Pavlic & EU821904 & EU821874 \\
\hline & CBS 123646 & CMW 14060 & S. cordatum & South Africa & D. Pavlic & EU821905 & EU821875 \\
\hline \multirow[t]{2}{*}{ N. occulatum } & CBS 128008 & MUCC227 & Eucalyptus grandis & Australia & T. Burgess & EU301030 & EU339509 \\
\hline & WAC12395 & MUCC286 & Eucalyptus pellita & Australia & T. Burgess & EU736947 & EU339511 \\
\hline \multirow[t]{2}{*}{ N. algeriense } & CBS 137504 & $A L G 1$ & Vitis vinifera & Algeria & A. Berraf-Tebbal & KJ657702 & KJ657715 \\
\hline & ALG9 & & V. vinifera & Algeria & A. Berraf-Tebbal & KJ657704 & KJ657721 \\
\hline \multirow[t]{2}{*}{ N. andinum } & CBS 117453 & $C M W 13455$ & Eucalyptus sp. & Venezuela & S. Mohali & AY693976 & AY693977 \\
\hline & CBS 117452 & CMW 13446 & Eucalyptus sp. & Venezuela & S. Mohali & DQ306263 & DQ306264 \\
\hline \multirow[t]{2}{*}{ N. nonquaesitum } & CBS 126655 & PD484 & Umbellularia californica & USA & F. P. Trouillas & GU251163 & GU251295 \\
\hline & PD301 & & Vaccinum corymbosum & Chile & $\begin{array}{l}\text { E. X. Briceno, J.G. Espinoza, } \\
\text { B.A. Latorre }\end{array}$ & GU251164 & GU251296 \\
\hline
\end{tabular}




\begin{tabular}{|c|c|c|c|c|c|c|c|}
\hline Species & Isolate ID $^{\mathrm{a}, \mathrm{b}}$ & Other ID $^{\mathrm{a}, \mathrm{b}}$ & Host & Country & Collector/isolator & ITS & EF \\
\hline \multirow{2}{*}{ N. arbuti } & CBS 116131 & & Arbutus menziesii & USA & M. Elliott & AY819720 & KF531792 \\
\hline & CBS 117090 & & A. menziesii & USA & M. Elliott & AY819724 & KF531791 \\
\hline \multirow[t]{2}{*}{ N. macroclavatum } & CBS 118223 & WAC12444 & Eucalyptus globulus & Australia & T. Burgess & DQ093217 & DQ093217 \\
\hline & WAC12445 & CMW 15948 & E. globulus & Australia & T. Burgess & DQ093218 & DQ093219 \\
\hline \multirow[t]{3}{*}{ N. eucalyptorum } & CBS 115791 & $C M W 10125$ & E. grandis & South Africa & H. Smith & AF283686 & AY236891 \\
\hline & CMW 10126 & & E. grandis & South Africa & H. Smith & AF283687 & AY236892 \\
\hline & CMW 11705 & & E. nitens & South Africa & B. Slippers & AY339256 & AY339264 \\
\hline \multirow[t]{2}{*}{ N. eucalypticola } & $C B S 115679$ & $C M W 6539$ & Eucalyptus grandis & Australia & M.J. Wingfield & AY615141 & AY615133 \\
\hline & CMW 6217 & CBS 115766 & Eucalyptus rossii & Australia & M.J. Wingfield & AY615143 & AY615135 \\
\hline \multirow[t]{2}{*}{ N. mangiferae } & CBS 118531 & CMW 7024 & Mangifera indica & Australia & G.I. Johnson & AY615185 & DQ093221 \\
\hline & CBS 118532 & CMW 7797 & M. indica & Australia & G.I. Johnson & AY615186 & DQ093220 \\
\hline \multirow[t]{2}{*}{ N. vitifusiforme } & CBS 110887 & STE-U 5252 & Vitis vinifera & South Africa & J.M. van Niekerk & AY343383 & AY343343 \\
\hline & CBS 110880 & STE-U 5050 & $V$. vinifera & South Africa & J.M. van Niekerk & AY343382 & AY343344 \\
\hline \multirow[t]{9}{*}{ N. eucalypti } & CMW 24460 & & E. pilularis & South Africa & H.M. Maleme & FJ752737 & FJ752706 \\
\hline & CMW 23791 & & Eucalyptus sp. & South Africa & H.M. Maleme & FJ752738 & FJ752705 \\
\hline & CMW 24571 & & E. paniculata & South Africa & H.M. Maleme & FJ752739 & FJ752707 \\
\hline & CMW 15952 & & E. diversicolor & Australia & T. Burgess, K.L. Goei & DQ093194 & DQ093215 \\
\hline & CMW 15953 & & E. diversicolor & Australia & T. Burgess, K.L. Goei & DQ093195 & DQ093216 \\
\hline & WAC12401 & PD293 & E. pauciflora & Australia & P. J. Keane & AY744372 & GU251305 \\
\hline & WAC 12402 & PD294 & E. camaldulensis & Australia & G. Whyte & AY744373 & GU251306 \\
\hline & WAC12398 & CMW 15198 & E. diversicolor & Australia & T. I. Burgess, K.L. Goei & AY744371 & DQ093214 \\
\hline & CBS 121767 & CMW 25409 & Acacia mellifera & Namibia & F.J.J van der Walt, J. Roux & EU101302 & EU101347 \\
\hline \multirow[t]{3}{*}{ N. protearum } & CMW 39282 & & A.karroo & South Africa & F. Jami & KF270043 & KF270013 \\
\hline & CMW 39280 & & A.karroo & South Africa & F. Jami & KF270041 & KF270011 \\
\hline & CMW 39281 & & A.karroo & South Africa & F. Jami & KF270042 & KF270012 \\
\hline \multirow[t]{2}{*}{ N. ursorum } & CBS 122811 & $C M W 24480^{C}$ & Eucalyptus camaldulensis & South Africa & H.M. Maleme & FJ752746 & FJ752709 \\
\hline & CMW 23790 & & Eucalyptus camaldulensis & South Africa & H.M. Maleme & FJ752745 & FJ752708 \\
\hline \multirow[t]{3}{*}{ N. mediterraneum } & CBS 121718 & $P D 312$ & Eucalyptus sp. & Greece & $\begin{array}{l}\text { P.W. Crous, M.J. Wingfield, } \\
\text { A.J.L. Phillips }\end{array}$ & GU251176 & GU251308 \\
\hline & PD2 & & Eucalyptus sp. & USA & T.J. Michailides & GU251178 & GU251310 \\
\hline & CBS 121558 & & Olea europea & Italy & F. Salvatore & GU799463 & GU799462 \\
\hline \multirow[t]{2}{*}{ N. viticlavatum } & CBS 112878 & STE-U 5044 & Vitis vinifera & South Africa & F. Halleen & AY343381 & AY343342 \\
\hline & CBS 112977 & STE-U 5041 & V. vinifera & South Africa & F. Halleen & AY343380 & AY343341 \\
\hline \multirow[t]{6}{*}{ N. cryptoaustrale } & CBS 1122813 & $C M W 23785^{C}$ & Eucalyptus sp. & South Africa & H.M. Maleme & FJ752742 & FJ752713 \\
\hline & CMW 23786 ${ }^{\text {c }}$ & & E. saligna & South Africa & H.M. Maleme & FJ752744 & FJ752714 \\
\hline & CMW 23787 & & E. dorrigoensis & South Africa & H.M. Maleme & FJ752743 & FJ752711 \\
\hline & CMW 23784 & & Eucalyptus sp. & South Africa & H.M. Maleme & FJ752741 & FJ752712 \\
\hline & CMW 20738 ${ }^{\mathrm{c}}$ & & E. citriodora & South Africa & H.M. Maleme & FJ752740 & FJ752710 \\
\hline & CAD023 & & Vitis vinifera & Italy & A. Deidda & KJ638328 & KJ638346 \\
\hline \multirow[t]{3}{*}{ N. australe } & $C M W 6837$ & & Acacia sp. & Australia & M.J. Wingfield & AY339270 & AY339270 \\
\hline & CMW 37396 & & Eucalyptus grandis & South Africa & M. Gryzenhout & JQ744576 & JQ744597 \\
\hline & CMW 15951 & & E. diversicolor & Australia & T. Burgess, K.L. Goei & DQ093201 & DQ093225 \\
\hline \multirow[t]{2}{*}{ N. luteum } & CBS 110299 & & Vitis vinifera & Portugal & A.J.L. Phillips & AY259091 & AY573217 \\
\hline & CBS 110497 & & $V$. vinifera & Portugal & A.J.L. Phillips & EU673311 & EU673277 \\
\hline
\end{tabular}




\begin{tabular}{|c|c|c|c|c|c|c|c|}
\hline Species & 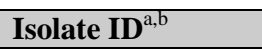 & Other ID $^{\mathrm{a}, \mathrm{b}}$ & Host & Country & Collector/isolator & ITS & EF \\
\hline \multirow[t]{9}{*}{ Botryosphaeria dothidea } & CBS 115476 & $C M W 8000$ & Prunus sp. & Switzerland & B. Slippers & AY236949 & AY236898 \\
\hline & MUCC500 & & Eucalyptus marginata & Australia & K. Taylor & EF591915 & EF591968 \\
\hline & MUCC501 & & E. marginata & Australia & K. Taylor & EF591916 & EF591969 \\
\hline & CMW 20717 & & E. citriodora & South Africa & H.M. Maleme & FJ752749 & FJ752720 \\
\hline & CMW 20732 & & E. citriodora & South Africa & H.M. Maleme & FJ752750 & FJ752721 \\
\hline & CMW 20728 & & E. saligna & South Africa & H.M. Maleme & FJ752747 & FJ752722 \\
\hline & CMW 20739 ${ }^{c}$ & & E. microcorys & South Africa & H.M. Maleme & FJ752751 & FJ752719 \\
\hline & CMW 20718 & & E. tereticornis & South Africa & H.M. Maleme & FJ752748 & FJ752723 \\
\hline & CMW 23783 & & E. dorrigoensis & South Africa & H.M. Maleme & FJ752752 & FJ752718 \\
\hline B. auasmontanum & $C B S 121769$ & $C M W 25413$ & Acacia mellifera & Namibia & F.J.J. van der Walt, J. Roux & EU101303 & EU101348 \\
\hline \multirow[t]{2}{*}{ B. scharifii } & CBS 124703 & IRAN 1529C & Mangifera indica & Iran & J. Abdollahzadeh & JQ772020 & JQ772057 \\
\hline & CBS 124702 & IRAN 1543C & M. indica & Iran & J. Abdollahzadeh, A. Javadi & JQ772019 & JQ772056 \\
\hline B. ramosa & CBS 122069 & $C M W 26167$ & Eucalyptus camaldulensis & Australia & T.I. Burgess, M.J. Wingfield & EU144055 & EU144070 \\
\hline \multirow[t]{2}{*}{ B. agaves } & CBS 133992 & MFLUCC 11-0125 & Agave sp. & Thailand & R. Phookamsak & JX646791 & JX646856 \\
\hline & MFLUCC 10-0051 & & Agave sp. & Thailand & P. Chomnuti & JX646790 & JX646855 \\
\hline \multirow[t]{2}{*}{ B. corticis } & CBS 119047 & CAP 197 & Vaccinium corymbosum & USA & P.V. Oudemans & DQ299245 & EU017539 \\
\hline & ATCC 22927 & & Vaccinium sp. & USA & R.D. Millholland & DQ299247 & EU673291 \\
\hline \multirow[t]{2}{*}{ B. fabicerciana } & $C B S 127193$ & $C M W 27094$ & Eucalyptus sp. & China & M.J. Wingfield & HQ332197 & HQ332213 \\
\hline & CMW 27108 & & Eucalyptus sp. & China & M.J. Wingfield & HQ332200 & HQ332216 \\
\hline B. fusispora & MFLUCC 10-0098 & & Entada sp. & Thailand & S. Boonmee & JX646789 & JX646854 \\
\hline
\end{tabular}

${ }^{a}$ Culture collections: CMW = Tree Protection Co-operative Programme, Forestry and Agricultural Biotechnology Institute, University of Pretoria; ATCC = American Type Culture

Collection, Fairfax, VA, USA; CAP = Culture collection of A. J. L. Phillips, Lisbon, Portugal; CBS = Centraalbureau voor isolates Schimmelcultures, Utrecht, Netherlands; CPC =

Culture Collection of P.W. Crous, housed at CBS; MFLUCC = Mae Fah Luang University Culture Collection;, Chiang Rai, Thailand; MUCC = Culture Collection, Laboratory of Plant Pathology, Mie University, Tsu, Mie prefecture, Japan; IRAN = Iranian Fungal Culture Collection, Iranian Research Institute of Plant Pathology, Iran; PD = Culture collection, University of California, Davis, USA; CAD = Collection A. Deidda; STE-U = Culture collection of the Department of Plant Pathology, University of Stellenbosch, South Africa; WAC = Department of Agriculture, Western Australia Plant Pathogen Collection, South Perth, Western Australia; CMM = Phytopathogenic Fungi of the Universidad Federal Rural de Pernambuco; ALG = Personal culture collection A. Berraf-Tebbal.

${ }^{\mathrm{b}}$ Isolates sequenced in this study are given in bold and isolates connected to type material are given in italics.

${ }^{\mathrm{c} I s o l a t e s}$ used in the pathogenicity tests. 


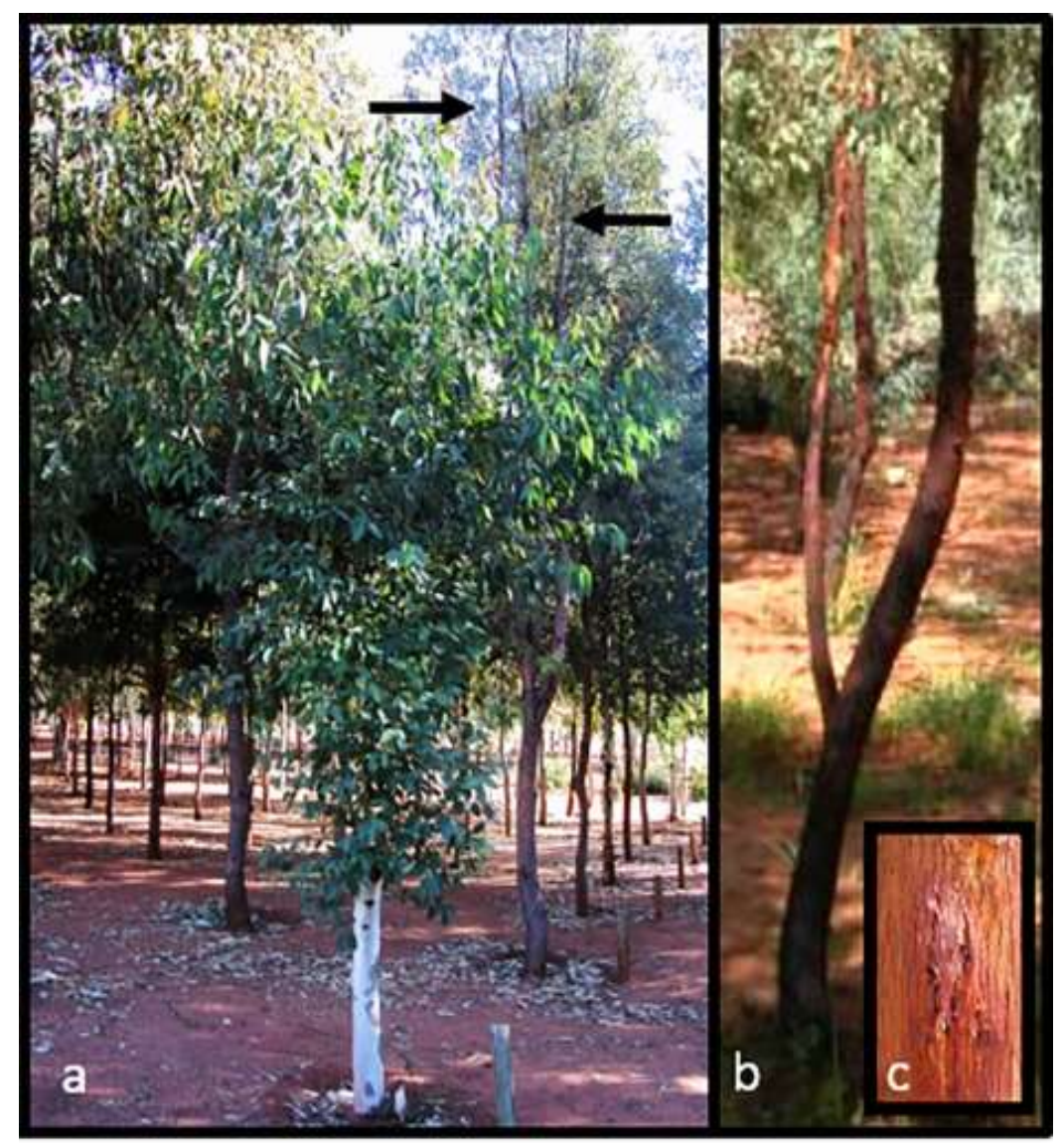

Fig. 1 The Pretoria arboretum that includes 20 Eucalyptus species. Twig die-back on terminal leader shoot is indicated by arrows (a). Main stem cankers spread widely on the trunks of a tree that appeared reddish in colour due to the extensive production of kino (b). Cankers are identified as cracks in the bark exuding kino (c).

\section{Morphological characteristics}

Isolates were induced to sporulate on sterilized pine needles (Smith et al. 2001) placed on 2 $\%$ water agar (WA) (Agar; Biolab, South Africa) and incubated at $25{ }^{\circ} \mathrm{C}$ under near-UV light. Pycnidia formed on pine needles after two to three weeks of incubation. Masses of conidia oozing from the pycnidia were mounted in $85 \%$ lactic acid on microscopic slides and examined using a light microscope. Images were captured using an HRc Axiocam digital camera and accompanying software (Carl Zeiss Ltd., Munich, Germany). Conidia (20-50) and 50 conidiogenous cells were measured for each isolate. Colony morphology and colour 
were noted for cultures grown on $2 \%$ malt extract agar (MEA) (Biolab, South Africa) at 25 ${ }^{\circ} \mathrm{C}$ and culture colours were defined using the colour charts of Rayner (1970). Growth studies were conducted for selected isolates at temperatures ranging from $10-35^{\circ} \mathrm{C}$ at $5{ }^{\circ} \mathrm{C}$ intervals in the dark. Two dishes were prepared for each isolate and two measurements of colony diameter perpendicular to each other were made daily until growth reached the edges of the $90 \mathrm{~mm}$ plates.

\section{DNA extraction and PCR amplification}

Single conidial or single hyphal tip cultures were grown on $2 \%$ MEA at $25{ }^{\circ} \mathrm{C}$ for 7 days. The mycelium was scraped directly from the medium and transferred to Eppendorf tubes (1.5 $\mathrm{ml})$ and $300 \mu \mathrm{l}$ of an extraction buffer $(200 \mathrm{mM}$ Tris- $\mathrm{HCl} \mathrm{pH} 8.5,150 \mathrm{mM} \mathrm{NaCl}, 25 \mathrm{mM}$ EDTA, $0.5 \%$ SDS) was added. A modified phenol:chloroform method for DNA extraction was followed (Raeder and Broda 1985). The resulting DNA pellets were re-suspended in 30 $\mu 1$ sterile SABAX water. RNAse $\left(1 \mathrm{mg} \mu \mathrm{l}^{-1}\right)$ was added to DNA suspensions and left overnight at the room temperature for RNA degradation. DNA electrophoresis was performed on a $1.5 \%$ agarose gel, stained with ethidium bromide. Bands were visualised under ultraviolet light. DNA concentration was estimated against a $\lambda$ standard size marker.

The ITS region was amplified using primers ITS 1 and ITS 4 (White et al. 1990) and a portion of the TEF-1 $\alpha$ gene region, was amplified with primer set EF-AF and EF-BR (Sakalidis et al. 2011). The reaction mixture contained 2.5 units of Taq polymerase (Roche Molecular Biochemicals, Almeda, California), $10 \times$ PCR buffer with $\mathrm{MgCl}_{2}(10 \mathrm{mM}$ Tris$\mathrm{HCl}, 1.5 \mathrm{mM} \mathrm{MgCl} 2,50 \mathrm{mM} \mathrm{KCl}), 0.2 \mathrm{mM}$ dNTPs and $10 \mathrm{mM}$ of each primer. The reaction mixture was made up to the final volume of $25 \mu \mathrm{l}$ with sterile water. The following PCR program was used: denaturation at $94{ }^{\circ} \mathrm{C}$ for 2 min followed by 40 cycles of denaturation at 
$94{ }^{\circ} \mathrm{C}$ for $30 \mathrm{~s}$, annealing temperature at $55{ }^{\circ} \mathrm{C}$ for $45 \mathrm{~s}$, elongation at $72{ }^{\circ} \mathrm{C}$ for $1 \frac{1}{2} \mathrm{~min}$ and a final elongation step at $72{ }^{\circ} \mathrm{C}$ for $5 \mathrm{~min}$. The PCR amplicons were viewed on a $1 \%$ agarose gel, stained with ethidium bromide under UV-light. To estimate the band sizes, a $100 \mathrm{bp}$ marker XIV (Roche Molecular Biochemicals, Almeda, California) was used.

\section{PCR-RFLP analysis}

A PCR-RFLP technique was used on the ITS amplicons to group all the isolates resembling Botryosphaeriaceae based on culture morphology. ITS rDNA amplicons were digested with the restriction enzymes (RE) HhaI that recognises the same sequences as $C f o \mathrm{I}$ that had been previously used to distinguish species of the Botryosphaeriaceae (Slippers et al. 2007). The PCR-RFLP reaction mixture for each reaction consisted of $20 \mu \mathrm{L}$ PCR product, $0.3 \mu \mathrm{L}$ RE Hha I and $2.5 \mu \mathrm{L}$ of the matching enzyme buffer (Fermentas, South Africa). The reaction mixture was incubated at $37{ }^{\circ} \mathrm{C}$ overnight. Digested fragments were separated on a $3 \%$ agarose gel run at a low voltage $(60 \mathrm{~V})$ for 1 hour.

\section{DNA sequencing and phylogenetic analysis}

Representative isolates from each of three groups identified based on PCR-RFLP analyses were sequenced using the primers that were used for the PCR amplification. The sequences were compared to those of known Botryosphaeriaceae obtained from GenBank, with a focus on those previously isolated from Eucalyptus (Table 1). Sequencing of the purified products was carried out by using ABI PRISM $3100^{\mathrm{TM}}$ automated DNA sequencer (Perkin-Elmer). Nucleotide sequences were analysed and edited using SEQUENCE NAVIGATOR version 1.0.1. (Perkin- Elmer Applied Bio-Systems, Foster City, CA) software. Online software, 
MAFFT version 7 under E-INS-i algorithm was used for alignments (Katoh et al. 2013). Maximum likelihood analyses using 10,000 rapid bootstrap inferences (command $\mathrm{f}-\mathrm{a}$ ) under the GTRGAMMA model were run in RAxML version 8.1.20 (Stamatakis 2014) for each dataset. Trees were displayed using FigTree version 1.3.1 (A. Rambaut: http:// tree.bio.ed.ac.uk/software/figtree).

\section{Pathogenicity}

Thirteen isolates representing the five species of the Botryosphaeriaceae identified in this study were used in pathogenicity tests in a greenhouse (Table 1). The selected isolates represented two or three of the fastest growing isolates. The isolates selected for pathogenicity tests were grown on MEA at $25{ }^{\circ} \mathrm{C}$ under continuous near-fluorescent light for seven days prior to inoculation. Two-year-old Eucalyptus grandis clone (ZG-14) trees were maintained in a greenhouse for approximately three weeks prior to inoculations to allow them to acclimatize. The greenhouse was exposed to natural day and night conditions and maintained at a constant temperature of approximately $25^{\circ} \mathrm{C}$. Each of the selected 13 isolates was inoculated onto the stems of ten trees. For controls, 30 trees were inoculated with sterile MEA plugs. For inoculations, wounds were made on the stems of trees approximately 250 $\mathrm{mm}$ above the soil level using $8 \mathrm{~mm}$ diameter cork borer. Plugs were prepared from sevenday-old cultures using the same size cork borer. The plugs were placed into wounds with the mycelium facing the exposed cambium and sealed with laboratory film (Parafilm "M", Pechiney Plastic Packaging, Chicago, U.S.A) to prevent desiccation and contamination. Lesion lengths were measured six weeks after inoculation. Re-isolation of the fungi from resulting lesions was done by cutting small pieces of the wood from the edge of lesions and plating these on $2 \% \mathrm{MEA}$ at $25{ }^{\circ} \mathrm{C}$. The entire trial was repeated once to verify the 
pathogenicity of all isolates under the same conditions. Lesion lengths that developed six weeks after inoculation were used as a measure of the pathogenicity. SAS® version 8.2 (2001) was used for statistical analysis of the data.

\section{Results}

\section{Morphological characteristics}

Ninety-two isolates were obtained from Eucalyptus spp. considered in this study. Forty-four of the 92 isolates produced asexual fruiting structures on WA overlaid with sterilized pine needles. No sexual structures were observed in any of the cultures. Two groups were identified based on conidial morphology and length to width (L/W) ratios. The first group of isolates (76 in total) had hyaline conidia that were aseptate, smooth with granular contents, fusiform to ellipsoid with apices rounded, occasionally (some of them) becoming brown and 1-2-septate with age, with a $\mathrm{L} / \mathrm{W}$ ratio < 4.0 (2.8-3.9). The isolates in the second group (16 in total) had hyaline, aseptate, narrowly to irregularly fusiform conidia, with a $\mathrm{L} / \mathrm{W}$ ratio $\geq 4.0$. Based on these characteristics these two groups can be linked to two genera in Botryosphaeriaceae, namely Neofusicoccum (group I), and Botryosphaeria (group II).

\section{PCR-RFLP analysis}

All 92 isolates were used for PCR-RFLP analyses. Three profiles (restriction length polymorphism fingerprints) were observed after digesting ITS rDNA PCR product with RE HhaI, indicating three groups for all the isolates. The seventy-six isolates from morphological 
group I were linked to two PCR-RFLP profiles with 66 having profile A and 10 profile $\mathrm{B}$. The sixteen isolates from the morphological group II were all linked to the profile C.

\section{DNA sequencing and analysis}

Twenty-nine representative isolates from all three groups identified based on the PCR-RFLP fingerprints (profile $\mathrm{A}=13$, profile $\mathrm{B}=10$, and profile $\mathrm{C}=6$ isolates), were selected for ITS $\mathrm{r}$ DNA sequencing of which nineteen (representing each species identified based on the ITS $r$ DNA sequences) were successively sequenced for TEF-1 $\alpha$ (Table 1). Sequences of approximately 550 bp (ITS rDNA) and 300 bp (TEF-1 $\alpha$ ) were obtained. For phylogenetic analyses, the final nucleotide matrices consisted of 22 and 85 ITS rDNA sequences for genera Botryosphaeria and Neofusicoccum, respectively (ITS data not shown). There were 22 concatenated ITS+TEF-1 $\alpha$ sequences for Botryosphaeria and 73 concatenated ITS+TEF-1 $\alpha$ sequences for Neofusicoccum. Of these, thirteen to six, respectively, represented isolates obtained in this study, while other sequences were those for known species of Neofusicoccum and Botryosphaeria, mostly representing those previously isolated from Eucalyptus (Table 1). Best maximum likelihood (ML) trees for Botryosphaeria were rooted against $N$. parvum and N. ribis. For Neofusicoccum, B. dothidea and B. cortices were used as outgroups. Final ML Optimization Likelihood for the Neofusicoccum concatenated ITS+TEF-1 $\alpha$ dataset was 2051.439865, and -3098.108649 for Botryosphaeria dataset. All isolates obtained in this study grouped into five different clades representing $N$. parvum, Dichomera eucalypti, $N$. ursorum and N. cryptoaustrale (Fig. 2) and Botryosphaeria dothidea (Fig. 3). The two subclades were observed within $N$. parvum clade in phylogenetic analyses of combined TEF- $1 \alpha$ and ITS rDNA sequence data sets (Fig. 2), however there was no congruency between phylogenetic analyses of individual data sets. Therefore, the isolates within this clade were 


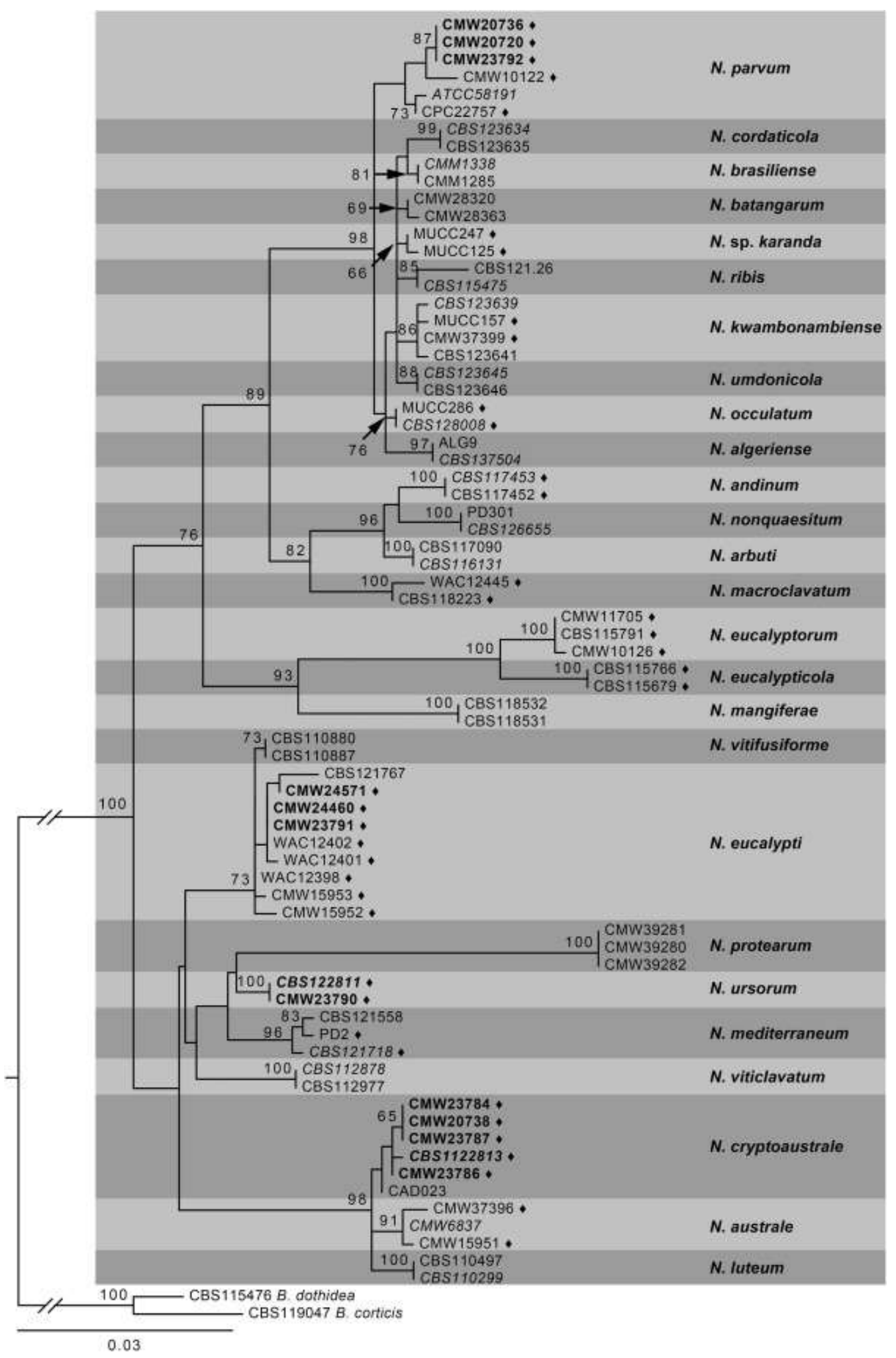

Fig. 2 Phylogenetic tree obtained from the combined sequence datasets of the ITS rDNA and EF-1 $\alpha$ loci for Neofusicoccum species. Bootstrap values $\geq 65$ based on 10000 bootstrap replicates are shown. Isolates sequenced in this study are in bold, isolates related to type specimens are in italics and isolates from Eucalyptus are marked as $\downarrow$. The tree is rooted to Botryosphaeria dothidea and B. corticis. 


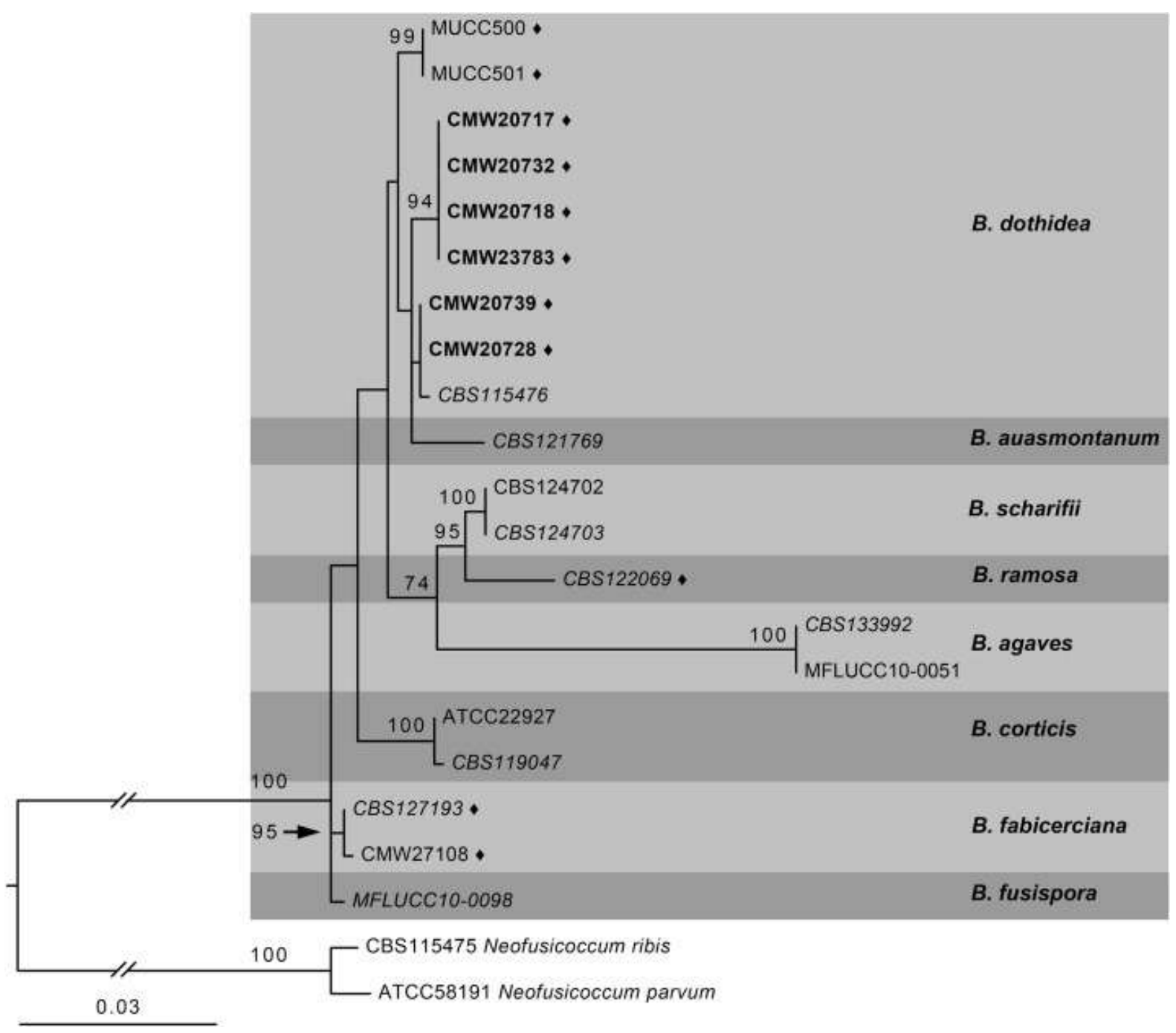

Fig. 3 Phylogenetic tree obtained from the combined sequence datasets of the ITS rDNA and EF-1 $\alpha$ loci for Botryosphaeria species. Bootstrap values $\geq 65$ based on 10000 bootstrap replicates are shown. Isolates sequenced in this study are in bold, isolates related to type specimens are in italic and isolates from Eucalyptus are marked as $\downarrow$. The tree is rooted to Neofusicoccum parvum and N. ribis.

identified as $N$. parvum. The isolates of $B$. dothidea from Eucalyptus in this study grouped within two sub-clades, while the two isolates obtained from Eucalyptus in Australia formed a third sub-clade (Fig. 3). These three sub-clades were observed in phylogenetic analyses of the ITS rDNA sequences (not shown) and of combined TEF-1 $\alpha$ and ITS rDNA sequence data sets (Fig. 3). Four fixed nucleotides were identified between ITS sequences in two sub-clades that included sequences obtained in this study, while there was no variation among TEF- $1 \alpha$ 
sequences. More isolates from these group and additional gene regions should be sequenced to confirm there is more than one species among these isolates. Based on analyses in this study they can be treated as B. dothidea sensu lato, or B. dothidea complex. With the use of the PCR-RFLP profiles and DNA sequence data, the number of isolates per species obtained from both Eucalyptus in the arboretum, as well as in the surrounding E. camaldulensis could be confirmed for all 92 isolates. The number of isolates representing the various Botryosphaeriaceae and their distribution on Eucalyptus spp. in the arboretum, as well as in the surrounding E. camaldulensis is presented in the Fig. 4.

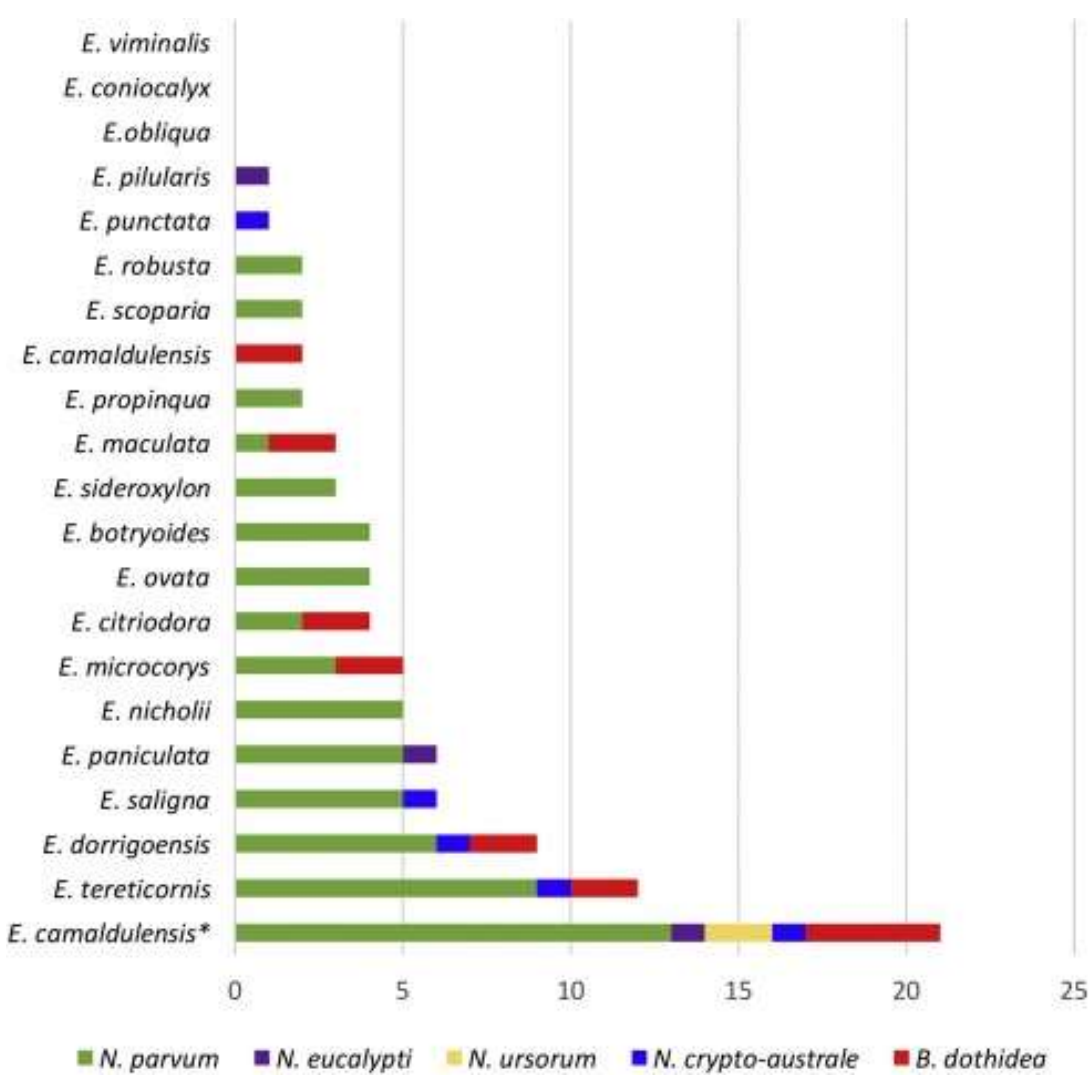

Fig. 4 Distribution of five Botryosphaeriaceae isolated from 20 different Eucalyptus spp. in the Pretoria arboretum and from (*) surrounding E. camaldulensis trees.

\section{Taxonomy}

Dichomera eucalypti was grouped firmly in the Neofusicoccum clade in this and other recently published studies (Barber et al. 2005; Burgess et al. 2005; Crous et al. 2006; Slippers 
et al. 2013; Phillips et al. 2013). Neofusicoccum is represented by species with Fusicoccumlike conidia sometimes having Dichomera-like synanamorphs (Crous et al. 2006). Fusicoccum-like conidia were observed in this study as opposed to muriform, globose conidia observed in the previous studies. Based on these morphological observations and the phylogenetic grouping of our isolates with isolates from Barber et al. (2005) (Fig. 2), which were morphologically linked to the epitype, this taxon was transferred to Neofusicoccum as Neofusicoccum eucalypti (Winter) Maleme, Pavlic \& Slippers comb. nov. (Maleme 2008).

\section{Pathogenicity}

The data were analyzed separately for each of the two trials and because there was no significant difference between them, these data were subsequently combined. All isolates inoculated on the Eucalyptus grandis clone ZG-14 produced lesions after six weeks that were significantly larger than those of the controls $(\mathrm{R}$-square $=0.58$, Coefficient variable $=39.7$, Root MES = 16.2), confirming their pathogenicity on this host (Fig. 5). The isolates were recovered by re-isolations from the lesions. Although some minor lesion development was observed on some of the control trees, no Botryosphaeriaceae could be re-isolated from these lesions.

The most aggressive of the isolates was a single isolate of $N$. eucalypti (CMW 24571) and two isolates of $N$. cryptoaustrale (CMW 23785 and CMW 23786). The lesions produced by these isolates on one Eucalyptus clone were significantly longer than those of all other isolates used in the inoculation tests but some isolates of these species had lower levels of aggressiveness (Fig. 5). On average, B. dothidea isolates were the least aggressive, while $N$. cryptoaustrale and $N$. parvum the most aggressive of the species tested (Fig. 5). 


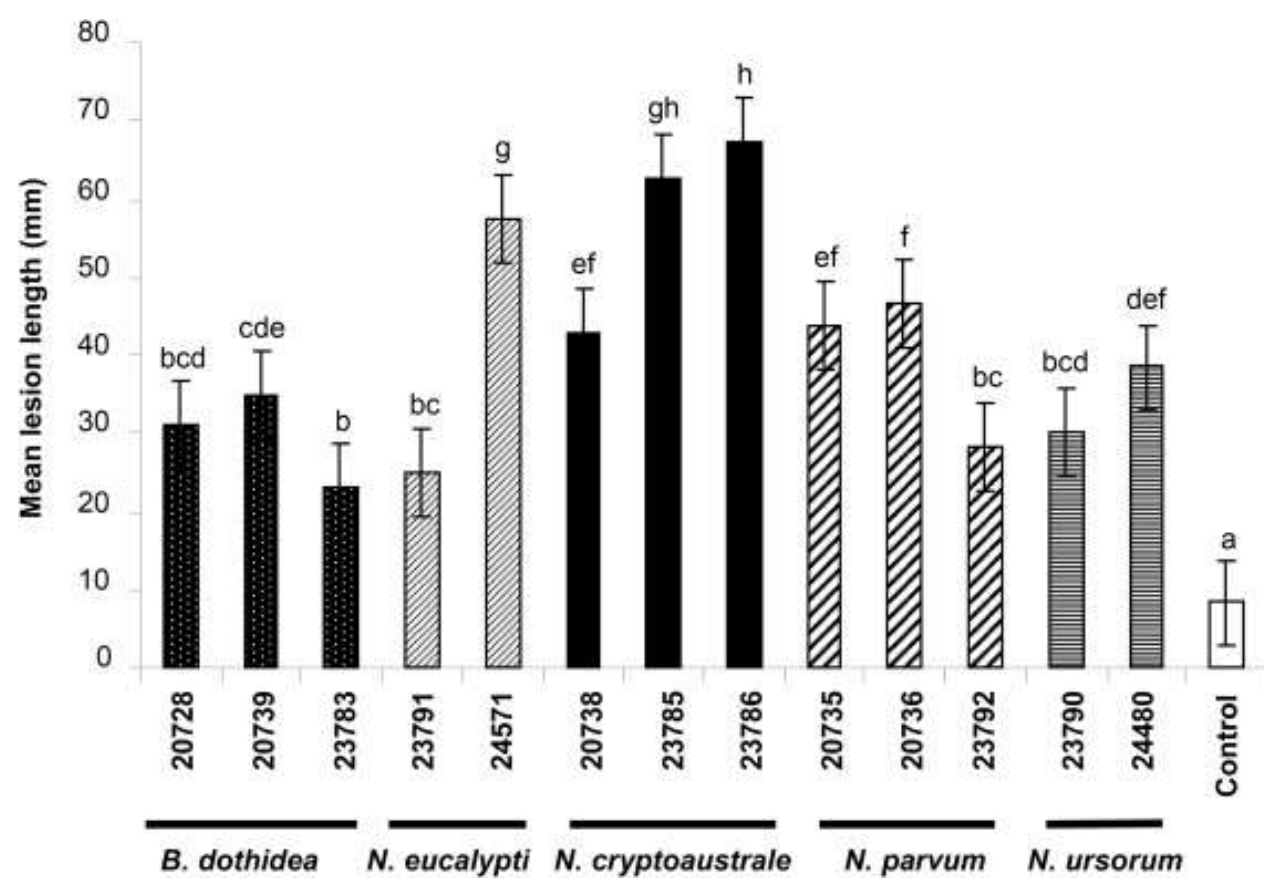

Fig. 5 Mean lesion lengths $(\mathrm{mm})$ for isolates of five species of Botryosphaeriaceae after inoculation on a Eucalyptus grandis clone (ZG-14), including Botryosphaeria dothidea, Neofusicoccum eucalypti, N. cryptoaustrale, N. parvum, N. ursorum. Control inoculations were done with MEA agar. Bars indicate the $95 \%$ confidence limit for each isolate.

\section{DISCUSSION}

Five species of the Botryosphaeriaceae, Botryosphaeria dothidea, Neofusicoccum parvum, N. cryptoaustrale, N. ursorum, and N. eucalypti (Winter) Maleme, Pavlic \& Slippers comb. nov. were identified from 20 Eucalyptus spp. planted in an arboretum in Pretoria, and from ornamental E. camaldulensis trees surrounding the arboretum. Most isolates were of $N$. parvum and B. dothidea. With exception of $N$. parvum which was isolated from majority of Eucalyptus spp. the other species were isolated from limited number of Eucalyptus species indicating host-preferences. Five identified species were shown to be able to produce lesions longer than those for the controls in artificial inoculations on one Eucalyptus grandis clone. Neofusicoccum eucalypti is recorded for the first time on Eucalyptus in South Africa. 
Neofusicoccum parvum was the most commonly isolated species in this study presenting $72 \%$ of all isolates. After its first description from kiwifruit in New Zealand (Pennycook \& Samuels 1985), this species has been recorded from more than 90 hosts, mostly woody angiosperms, across the globe (Phillips et al. 2002; Gure et al. 2005; Pavlic et al. 2007, Sakalidis et al. 2011). On Eucalyptus, it is commonly reported as a cause of canker and die-back (Nakabonge 2002; Ahumada 2003; Gezahgne et al. 2004; Barber et al. 2005; Mohali et al. 2006; Rodas et al. 2009; Chen et al. 2011; Iturritxa et al. 2011; Pillay et al. 2013). In South Africa, Neofusicoccum parvum is also known from native Myrtaceae, including Heteropyxis natalensis and Syzygium cordatum (Smith et al. 2001; Slippers et al. 2004; Pavlic et al. 2007, Pillay et al. 2013, Pavlic-Zupanc et al. 2015). Pavlic et al (2015) demonstrated that $N$. parvum is dominant and most abundant on $S$. cordatum in habitats influenced by human activity. Thus, its abundance on Eucalyptus species in an urban environment is not surprising.

Botryosphaeria dothidea was the second most common species obtained in this study, representing $17 \%$ of all isolates. This fungus has been documented on many hosts worldwide, including Eucalyptus (Smith et al. 1996, 2001; Yu et al. 2009; Pérez et al. 2010). Recent studies have indicated that this fungal species is not common on Eucalyptus and other closely related hosts in South Africa (Slippers et al. 2004; Pavlic et al. 2007; Pillay et al. 2013). In contrast, $B$. dothidea was the most common species identified on native Acacia karoo trees across the country (Jami et al. 2015). A few recent studies have also described $B$. dothidea as one of the most common Botryosphaeriaceae species on a variety of trees grown in native forests and as ornamental in urban habits in Europe (Piškur at al. 2010; Zlatkovic et al. 2016). Its dominant presence on Eucalyptus grown in the urban habitats, may indicate biotic exchange between Eucalyptus and diverse community of trees grown as ornamentals in the urban area of Pretoria, many of which have been introduced from other parts of the world. 
Three distinct, highly supported lineages were identified for B. dothidea isolates in phylogenetic analyses using DNA sequence data for the ITS rDNA and TEF- $1 \alpha$ gene regions. Two lineages comprised isolates of $B$. dothidea obtained in this study, while two isolates obtained from Eucalyptus in Australia form the third one. The Botryosphaeria dothidea complex was introduced for the first time by Smith et al. (2001) based on phylogenetic analyses of ITS sequence data obtained for a group of isolates from Eucalyptus in South Africa. High levels of variation have been observed among sequences of isolates identified as B. dothidea from different woody hosts in numerous studies (Smith et al. 2001; Burgess et al. 2005; Slippers et al 2007; Inderbitzin et al. 2010). In the latter study, based on a six-locus phylogeny, three lineages were resolved among isolates of $B$. dothidea from a variety of woody hosts including eucalypt. Those lineages were also correlated to distinct morphological characters. Results of the present study also suggest that isolates identified as B. dothidea could include cryptic species.

Neofusicoccum cryptoaustrale and $N$. ursorum were recently described from a plant tissue collected as a part of the current study (Crous et al. 2013). Neofusicoccum cryptoaustrale as a cryptic sister species to $N$. australe has previously been isolated from Wollemia nobilis, a native conifer in eastern Australia (Slippers et al. 2005) and on native Syzygium cordatum trees in South Africa (Pavlic et al. 2007). The occurrence of $N$. cryptoaustrale on two different native hosts in Australia and South Africa and on non-native Eucalyptus in South Africa, makes it difficult to suggest a possible origin for the fungus. Its existence on Eucalyptus spp. in South Africa could be explained by the movement of species of Botryosphaeriaceae between continents on plant material, possibly from Australia where Eucalyptus is native. Alternatively, it could had jumped hosts from native Syzygium cordatum to introduced Eucalyptus, or vice versa in South Africa since both hosts were shown to share similar pathogens (Pavlic et al. 2007; Pillay et al. 2013). Two isolates of Neofusicoccum 
ursorum were collected from E. camaldulensis growing around the arboretum. This species is currently known only from South Africa, and to the best of our knowledge, has never been reported from any other area or host globally.

Neofusicoccum eucalypti is established in this study as a new combination for Camarosporium eucalypti. The taxon was originally described from Eucalyptus spp. in Australia as producing globose, subglobose, obovoid, obpyriform, muriform or somewhat fusiform, septate conidia (Sutton 1975). This was confirmed by Barber et al. (2005) who designated an epitype specimen (and ex-type culture) for 'Dichomera eucalypti'. The isolates obtained in the present study were identical to the ex-type cultures in ITS rDNA and TEF-1 $\alpha$ sequence data, but did not have morphological characteristics described by Sutton (1975) and Barber et al. (2005). They rather produced hyaline, aseptate, fusiform to ellipsoid conidia in culture. This observation, together with the consistent grouping with other species of Neofusicoccum, validates our treatment of the fungus in Neofusicoccum as N. eucalypti. Some other Neofusicoccum species (e.g. N. parvum, N. australe, see Barber et al. (2005)) are also known to produce synanamorphs that are Dichomera-like. It remains unclear why some isolates, such as those found in this study, produce only one of the spore forms and not the other.

Neofusicoccum eucalypti is well known from woody tissues, foliage and bark samples of Eucalyptus spp. in Australia (Sutton 1975; Barber et al. 2005; Burgess et al. 2005). The species was not common in this study, with only two isolates of this species identified as endophytes from asymptomatic leaves in the Eucalyptus arboretum and one from the surrounding E. camaldulensis trees. This is the first report of this fungus on Eucalyptus in South Africa. Its occurrence on non-native Eucalyptus in South Africa might have been anticipated due to its common association with Eucalyptus in Australia and the fact that the trees sampled in this study were generated from seed originating in Australia. 
All the isolates tested in pathogenicity trial could infect two-year-old Eucalyptus grandis trees and produces lesions significantly longer than controls. The isolates of $N$. cryptoaustrale were the most virulent. Wide host and geographic range, as well as the high level of virulence revealed in this study, makes $N$. cryptoaustrale a potential threat to both native and non-native hosts in South Africa and Australia (Slippers et al. 2005, Pavlic et al. 2007). Although the isolates of $N$. eucalypti varied significantly in virulence, it is noteworthy that one of the isolates was amongst the most virulent in the pathogenicity trial. The presence of N. eucalypti in South Africa, albeit at low levels currently, poses a potential threat to Eucalyptus grandis. Although most commonly isolated, individual N. parvum isolates were pathogenic to Eucalyptus grandis, but when compared to other species studied here they were mildly virulent, followed by N. ursorum. Botryosphaeria dothidea isolates were on average the least virulent. This results are consistent with recent studies about $B$. dothidea and Neofusicoccum spp. pathogenicity on Myrtaceae species in South Africa, Venezuela and Colombia (Mohali et al. 2007; Pavlic et al. 2007; Rodas et al. 2009).

Numerous species of the Botryosphaeriaceae have been identified in recent years on Eucalyptus by combining both morphological characters and multigene phylogeny (Slippers et al. 2007; Chen et al 2011; Crous et al. 2013; Pillay et al 2013). Some are thought to be host specific and/or with a local distribution, such as B. fabicerciana and N. andinum that have been recorded only on Eucalyptus in China and Venezuela, respectively (Mohali et al. 2006, Chen et al. 2011; Phillips et al. 2013). Others have a broad host range and are more widely distributed, such as $N$. parvum that has been documented on Eucalyptus in countries such as South Africa, Venezuela, Uganda, China and Spain (Roux et al. 2000, 2001; Mohali et al. 2007; Chen et al. 2011; Iturritxa et al. 2011). The present study adds to this emerging global view of a combination of a few common generalists and some rare species of the 
Botryosphaeriaceae that infect Eucalyptus at any given location, not only in plantation forestry but in urban ecosystems.

\section{Acknowledgements}

We thank the National Research Foundation (NRF), members of the Tree Protection Cooperative Programme (TPCP), Department of Science and technology (DST/NRF Centre of Excellence in Tree Health Biotechnology (CTHB), South Africa, Department of Water affairs and Forestry, South Africa for the financial support. B. Piškur was provided with financial assistance of the Slovenian Research Agency (research program P4-0107 and research project Z4-5518).

\section{References}

Ahumada R (2003) Fungal diseases affecting Eucalyptus plantations in Chile. Dissertation, University of Pretoria.

Barber PA, Burgess TI, Hardy GEStJ, Slippers B, Keane PJ (2005) Botryosphaeria species from Eucalyptus in Australia are pleoanamorphic, producing Dichomera synanamorphs in culture. Mycological Research 109:1347-1363.

Burgess TI, Barber PA, Hardy GEStJ (2005) Botryosphaeria spp. associated with eucalypts in Western Australia, including the description of Fusicoccum macroclavatum sp. nov. Australasian Plant Pathology 34:557-567.

Burgess TI, Sakalidis ML, Hardy GEStJ (2006) Geneflow of the canker pathogen Botryosphaeria australis between Eucalyptus globulus plantations and native eucalypt forests in Western Australia. Australian Ecology 31:559-566. 
Chen SF, Pavlic D, Roux J, Slippers B, Xie YJ, Wingfield MJ, Zhou XD (2011) Characterization of Botryosphaeriaceae from plantation-grown Eucalyptus species in South China. Plant Pathology 60:739-751.

Crous PW, Slippers B, Wingfield MJ et al (2006) Phylogenetic lineages in the Botryosphaeriaceae. Studies in Mycology 55:235-253.

Crous PW, Wingfield MJ, Guarro J et al (2013) Neofusicoccum ursorum sp. nov. and Neofusicoccum cryptoaustrale sp. nov. Fungal Planet description sheets 154-213. Persoonia 31:188-296.

Denman S, Crous PW, Taylor JW, Kang J-C, Pascoe I, Wingfield MJ (2000) An overview of the taxonomic history of Botryosphaeria, and a re-evaluation of its anamorphs based on morphology and ITS rDNA phylogeny. Studies in Mycology 45:129-140.

Desprez-Loustau ML, Marcais B, Nageleisen LM, Piou D, Vannini A (2006) Interactive effects of drought and pathogens in forest trees. Ann For Sci 63: 597-612.

Gezahgne A, Roux J, Slippers B, Wingfield MJ (2004) Identification of the causal agent of Botryosphaeria stem canker in Ethiopian Eucalyptus plantations. South African Journal of Botany 70:241-248.

Gure A, Slippers B, Stenlid J (2005) Seed-borne Botryosphaeria spp. from native Prunus and Podocarpus trees in Ethiopia, with a description of the anamorph Diplodia rosulata sp. nov. Mycological Research 109:1005-1014.

Inderbitzin P, Bostock RM, Trouillas FP, Michailides TJ (2010) A six locus phylogeny reveals high species diversity in Botryosphaeriaceae from California almond. Mycologia 102:1350-1368.

Iturritxa E, Slippers B, Mesanza N, Wingfield MJ (2011) First report of Neofusicoccum parvum causing canker and die-back of Eucalyptus in Spain. Australasian Plant Disease Notes 6:57-59. 
Jami F, Slippers B, Wingfield MJ, Loots MT, Gryzenhout M (2015) Temporal and spatial variation of Botryosphaeriaceae associated with Acacia karroo in South Africa. Fungal Ecology 15:51-62.

Katoh K, Standley DM (2013) MAFFT Multiple Sequence Alignment Software Version 7: Improvements in Performance and Usability. Mol Biol Evol 30:772-780.

Liu J-K, Phookamsak R, Doilom M et al (2012) Towards a natural classification of Botryosphaeriales. Fungal Diversity 57:149-210.

Lupo S, Tiscornia S, Bettuci L (2001) Endophytic fungi from flowers, capsules and seeds of Eucalyptus globulus. Revista Iberoam Mycology 18:38-41.

Maleme HM (2008) Characterization of latent Botryosphaeriaceae on diverse Eucalyptus species. Dissertation, University of Pretoria.

Mehl JWM, Slippers B, Roux J, Wingfield MJ (2013). Cankers and other diseases caused by the Botryosphaeriaceae. In: Infectious Forest Diseases. Gonthier P, Nicolotti G. (eds). CAB International. Boston, Minessota. Pp 298-317.

Mohali S, Slippers B, Wingfield MJ (2006) Two new Fusicoccum species from Acacia and Eucalyptus in Venezuela, based on morphology and DNA sequence data. Mycological Research 110:405-413.

Mohali SR, Slippers B, Wingfield MJ (2007) Identification of Botryosphaeriaceae from Eucalyptus, Acacia and Pinus in Venezuela. Fungal Diversity 25:103-125.

Nakabonge G (2002) Diseases associated with Plantation Forestry in Uganda. Dissertation, University of Pretoria

Pavlic D, Slippers B, Coutinho TA, Gryzenhout M, Wingfield MJ (2004) Lasiodiplodia gonobuensis sp. nov., a new Botryosphaeria anamorph from native Syzygium cordatum in South Africa. Studies in Mycology 50:313-322. 
Pavlic D, Slippers B, Coutinho TA, Wingfield MJ (2007) Botryosphaeriaceae occurring on native Syzygium cordatum in South Africa and their potential threat to Eucalyptus. Plant Pathology 56:624-636.

Pavlic-Zupanc D, Wingfield MJ, Boissin E, Slippers B (2015) The distribution of genetic diversity in the Neofusicoccum parvum / N. ribis complex suggests structure correlated with level of disturbance. Fungal Ecology 13:93-102.

Pennycook SR, Samuels GJ (1985) Botryosphaeria and Fusicoccum species associated with ripe fruit rot of Actinidia deliciosa (kiwifruit) in New Zealand. Mycotaxon 24:445-458.

Pérez CA, Wingfield MJ, Slippers B, Altier NA, Blanchette RA (2010) Endophytic and canker-associated Botryosphaeriaceae occurring on non-native Eucalyptus and native Myrtaceae trees in Uruguay. Fungal Diversity 41:53-69.

Phillips AJL, Alves A, Abdollahzadeh J, Slippers B, Wingfield MJ, Groenewald JZ, Crous PW (2013) The Botryosphaeriaceae: genera and species known from culture. Studies in Mycology 76:51-167.

Phillips AJL, Fonseca F, Povoa V, Castilho R, Nolasco G (2002) A reassessment of the anamorphic fungus Fusicoccum luteum and description of its teleomorph Botryosphaeria lutea sp. nov. Sydowia 54:59-77.

Pillay K, Slippers B, Wingfield MJ, Gryzenhout M (2013) Diversity and distribution of coinfecting Botryosphaeriaceae from Eucalyptus grandis and Syzygium cordatum in South Africa. South African Journal of Botany 84:38-43.

Raeder U, Broda P (1985). Rapid preparation of DNA from filamentous fungi. Letters in Applied Microbiology 1:17-20.

Rayner RW (1970) A Mycological colour chart. Commonwealth Mycological Institute, Kew.

Rodas CA, Slippers B, Gryzenhout M, Wingfield MJ (2009) Botryosphaeriaceae associated with Eucalyptus canker diseases in Colombia. Forest Pathology 39:110-123. 
Roux J, Coutinho TA, Byabashaija DM, Wingfield MJ (2001) Diseases of plantation Eucalyptus in Uganda. South African Journal of Science 97:16-18.

Roux J, Coutinho TA, Wingfield MJ, Bouillet J-P (2000) Diseases of plantation Eucalyptus in the Republic of Congo. South African Journal of Science 96:454-456.

Sakalidis ML, Hardy GEStJ, Burgess TI (2011) Use of the Genealogical Sorting Index (GSI) to delineate species boundaries in the Neofusicoccum parvum-Neofusicoccum ribis species complex. Molecular Phylogenetics and Evolution 60:333-344.

SAS Institute (2001) SAS Statistical software, SAS/STAT Users Guide, Version 8.2, Institute Inc., SAS Campus Drive, Cary, North Carolina 27513, USA.

Schoch CL, Shoemaker R, Seifert K, Hambleton S, Spatafore JW, Crous PW (2006) A multigene phylogeny of the Dothideomycetes using four nuclear loci. Mycologia 98:1041-1052.

Shoemaker RA (1964) Conidial states of some Botryosphaeria species on Vitis and Quercus. Canadian Journal of Botany 42:1297-1301.

Slippers B, Boissin E, Phillips AJL, Groenewald JZ, Lombard L, Wingfield MJ, Postma A, Burgess TI, Crous PW (2013) Phylogenetic lineages in the Botryosphaeriaceae: a systematic and evolutionary framework. Studies in Mycology 76:31-49.

Slippers B, Burgess T, Pavlic D, Ahumada R, Maleme H, Mohali S, Rodas C, Wingfield MJ (2009) A diverse assemblage of Botryosphaeriaceae infecting Eucalyptus in native and non-native environments. Southern Forests: A Journal of Forest Science 71:101110.

Slippers B, Fourie G, Crous PW, Coutinho TA, Wingfield BD, Carnegie JA, Wingfield MJ (2004) Speciation and distribution of Botryosphaeria spp. on native and introduced Eucalyptus trees in Australia and South Africa. Studies in Mycology 50:343-358. 
Slippers B, Pavlic D, Maleme H, Wingfield MJ (2007) A diverse assemblage of Botryosphaeriaceae infect Eucalyptus in introduced and native environments. Proceedings of IUFRO Conference, 22-26 August, Durban, South Africa.

Slippers B, Summerell BA, Crous PW, Coutinho TA, Wingfield BD, Wingfield MJ (2005). Preliminary studies on Botryosphaeria species for Southern Hemisphere conifers in Australasia and South Africa. Australasian Plant Pathology 34:213-220.

Slippers B, Wingfield MJ (2007) Botryosphaeriaceae as endophytes and latent pathogens of woody plants: diversity, ecology and impact. Fungal Biology Reviews 21:90-106.

Smith H, Crous PW, Wingfield MJ, Coutinho TA, Wingfield BD (2001) Botryosphaeria eucalyptorum sp. nov., a new species in the B. dothidea - complex on Eucalyptus in South Africa. Mycologia 93:277-284.

Smith H, Wingfield MJ, Petrini O (1996) Botryosphaeria dothidea endophytic in Eucalyptus grandis and Eucalyptus nitens in South Africa. Forest Ecology and Management 89:189-195.

Stamatakis A (2014) RAxML Version 8: A tool for phylogenetic analysis and post-analysis of large phylogenies. Bioinformatics 30:1312-1313.

Sutton BC (1975) The Coelomycetes V. Coryneum. Mycological Papers 138:1-224.

Taylor K, Barber PA, Hardy GEStJ, Burgess TI (2009) Botryosphaeriaceae from tuart (Eucalyptus gomphocephala) woodland, including descriptions of four new species. Mycological Research 113:337-53.

Yu L, Chen XL, Gao LL, H. Chen HR, Huang Q (2009) First Report of Botryosphaeria dothidea causing canker and shoot blight of Eucalyptus in China. Plant Disease 93:764.

White JJ, Bruns T, Lee S, Taylor J (1990) Amplification and direct sequencing of fungal ribosomal RNA genes for phylogenetic. In: Inns MA, Gelfand DH, Snisky JJ, White 
TJ (eds), PCR protocols: A Guide to Methods and Applications. Academic Press, San Diego, pp 315-322.

Wingfield MJ, Slippers B, Roux J, Wingfield BD (2001) Worldwide movement of exotic forest fungi, especially in the Tropics and the Southern hemisphere. Bioscience 51:134-140.

Wingfield MJ, Brockerhoff EG, Wingfield BD, Slippers B (2015) Planted forest health: The need for a global strategy. Science 349:832-836.

Zlatković M, Keča N, Wingfield MJ, Jami F, Slippers B (2016) Botryosphaeriaceae associated with ornamental trees in the Western Balkan. Antonie van Leeuwenhoek 109:543564. 